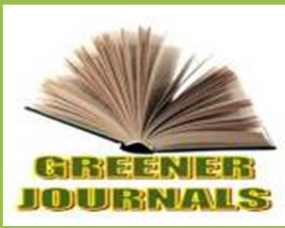

\title{
Metabolizable Energy and Digestibility Estimates of mixed Diets of Crop By- Products as Readily Available Feeds for Small Ruminants
}

\section{Godfrey Adokiye Kalio}

Department of Agricultural Science Ignatius Ajuru University of Education, PMB 5047, Ndele, Nigeria.

\section{ARTICLE INFO}

Article No.: 101417150

DOI: 10.15580/GJAS.2017.8.101417150

Submitted: $14 / 10 / 2017$

Accepted: $23 / 10 / 2017$

Published: $30 / 10 / 2017$

${ }^{\star}$ Corresponding Author

Godfrey Adokiye Kalio

E-mail: ag.kalio@yahoo.com

Phone: +2348033000589

\section{Keywords:}

Metabolizable energy, digestibility, in vitro gas production, crop byproducts, small ruminants, diets
The Metabolizable energy and digestibility estimates of mixed rations containing crop by-products as feeds for small ruminants was investigated using the in vitro gas production technique. Four concentrate feed mixtures of maize (TM), Cassava peel (TCP), Plantain peel (TPP) and Yam peel (TYP) in a roughage base of Panicum maximum in the ratio of $40 \%$ : $60 \%$ was formulated as potential readily available diets for small ruminants. Results reveal that the TCP supplemented energy based diets possess a higher ME value than the ME values for the plantain peel TPP, TM and TYP supplemented diets. The ME values recorded for TCP and TPP were within the recommended ME values for an average diet $(6-13$ $\mathrm{MJ} / \mathrm{kg} / \mathrm{DM}$ ); hence can fulfill the energy requirements for small ruminants when utilized. Similarly, the TYP and TPP treatment groups recorded the highest value of SCFAs, hence being a major source of energy as well as a building block for milk synthesis. The diet containing TCP recorded the highest organic matter digestibility (OMD) after 24 hours of incubation. It is therefore recommended that non-conventional feedstuffs such as crop by-products could be better substitutes as energy sources in sheep and goat diets on account of their nutritional value in terms of metabolizable energy (ME), short chain fatty acids (SCFAs) and organic matter digestibility (OMD) as well as their ready availability and predominance, cheapness and better economic gains to small ruminant farmers.. 


\section{INTRODUCTION}

The most difficult problem in ruminant production in the tropics is the insufficiency of energy and protein feedstuffs during the dry season (Adegbola et al., 1988). At this period, available forage are dry, the protein content is very low, there is marked decrease in voluntary intake and digestibility and the animals lose substantial weight. This has led to the search for cheap sources of energy and protein to complement the low quality forages during the dry season (Adegbola et al., 1988). Additionally, there is competition between animal species for the utilization of the feed resources, and also with humans for cereals and cereal by-products. These aspects are further exacerbated by limitations in the availability of land and inadequate production of feeds to meet the annual requirements of animals (Devendra, 1989).

The quality of feedstuff given to livestock can be evaluated by the product of the digestibility and metabolizable energy of such feed. Similarly, the preliminary use of the gas method will also be an ideal technique to generate kinetics of fermentation of test feeds, as this will allow recording of gas produced at several times in the incubation period to predict the rate at which the feed is digested and utilized by the ruminant. Consequently, due to the acute competition between livestock and man for feed/food, there is the need to explore alternative means of using nonconventional feed stuffs such as crop by-products as a way to escape the high cost of feeding confined sheep and goats, while at the same time improving their productivity as well as providing all round feeding for the year.

\section{MATERIAL AND METHODS}

\section{Site of the Experiment}

In vitro gas production studies were carried out at the Ruminant Nutrition Laboratory, University of Benin, Benin City, Nigeria.

\section{Procurement and processing of feed materials}

A four (4) weeks re-growth of Guinea grass (Panicum maximum) was harvested within the premises of Ignatius Ajuru University of Education Port Harcourt, Ndele Campus farm. The grasses were air dried for two (2) weeks to protect its nutritive content and later was chopped into smaller sizes using sharp machete. Different crop by-products: cassava peels, yam peels, and plantain peels were all collected from the rural women of Ndele Community who either disposes them at refuse dumps or as mere mulch materials on their crop farms. These peels were all sun-dried for the same period of two weeks. The conventional feed material (maize) was purchased from the market. These feed materials were all grinded separately using electric grinding machines and samples with particle size of $1 \mathrm{~mm}$ were utilized.

\section{Formulation of experimental small ruminant diets}

The feed mixtures (experimental diets) of maize and different crop by-products as the basal energy sources: cassava, yam, and plantain peels were formulated in the ratio of $40 \%: 60 \%$ ( $40 \%$ of concentrates including the basal energy sources and $60 \%$ of a roughage base Panicum maximum. The feed mixtures are presented in Table 1.

Table 1: Feed composition of the experimental diets

\begin{tabular}{lcccc}
\hline Feed Ingredients & $\mathbf{T}_{\mathbf{M}}$ (Maize) & $\begin{array}{c}\text { Treatment } \\
\mathbf{T}_{\mathbf{C P}} \\
\text { (Cassava } \\
\text { peels) }\end{array}$ & $\begin{array}{c}\mathbf{T}_{\mathbf{Y P}} \\
\text { (Yam peels) }\end{array}$ & $\begin{array}{c}\mathbf{T}_{\mathbf{P P}} \\
\text { (Plantain } \\
\text { peels) }\end{array}$ \\
\hline Maize (70\%) & 70.00 & 0.00 & 0.00 & 0.00 \\
Cassava peels (70\%) & 0.00 & 70.00 & 0.00 & 0.00 \\
Yam peels (70\%) & 0.00 & 0.00 & 70.00 & 0.00 \\
Plantain peels (70\%) & 0.00 & 0.00 & 0.00 & 70.00 \\
PKC (21\%) & 21.00 & 21.00 & 21.00 & 21.00 \\
Urea (2\%) & 2.00 & 2.00 & 2.00 & 2.00 \\
Common Salt (1\%) & 1.00 & 1.00 & 1.00 & 1.00 \\
Oyster shell (4.75\%) & 4.75 & 4.75 & 4.75 & 4.75 \\
Lime stone (1.00\%) & 1.00 & 1.00 & 1.00 & 1.00 \\
Fish Meal (0.25\%) & 0.25 & 0.25 & 0.25 & 0.25 \\
\hline Total Concentrate & $100 \mathrm{~kg}$ & $100 \mathrm{~kg}$ & $100 \mathrm{~kg}$ & $100 \mathrm{~kg}$ \\
Pannicum maximum & $\mathbf{4 0 \%}$ & $\mathbf{4 0 \%}$ & $\mathbf{4 0 \%}$ & $\mathbf{4 0 \%}$ \\
\hline
\end{tabular}


These feed ingredients were mixed together and from it $40 \%$ was measured out from each sample and added to $60 \%$ roughage already measured for each sample.

\section{In vitro gas production}

Rumen fluid was obtained from the Ram through suction tube before the morning feed (Babayemiet al., 2009) into a thermoflask that had been pre warmed to a temperature of $39^{\circ} \mathrm{C}$. The incubation procedure was as reported by Menke and Steingass (1988) using 120ml calibrated syringes in three batches at $39-40^{\circ} \mathrm{C} .200 \mathrm{mg}$ of the feed samples were weighed using a Gallenkamp oven (Oven BS Model OV-330 made in England) into the syringe and added to $30 \mathrm{ml}$ of inoculums containing cheese cloth strained rumen liquor and buffer ( $\mathrm{g} /$ /itre) of $9.8 \mathrm{~g} \mathrm{NaHCO}_{3}+2.77 \mathrm{~g}, \mathrm{Na}_{2} \mathrm{HPO}_{4}+0.57 \mathrm{~g}, \mathrm{KCl}+$ $0.47 \mathrm{~g}, \mathrm{NaCl}+0.12 \mathrm{~g}, \mathrm{MgSO}_{4} \cdot 7 \mathrm{H}_{2} \mathrm{O}+16 \mathrm{~g}, \mathrm{CaCl}_{2} \cdot 2 \mathrm{H}_{2} \mathrm{O}$.

Rumen liquor and buffer were mixed together $(1: 4, v / v)$ under continuous flushing with $\mathrm{CO}_{2}$. Using $50 \mathrm{ml}$ calibrated plastic syringe, $30 \mathrm{ml}$ of inoculums was dispensed into the substrate through the silicon tube . The plunger was pushed upward by pushing the inoculums to the tip of the syringe to completely eliminate air. The silicon tube in the syringe was then tightened by a metal clip so as to prevent escape of gas. The volume of gas production was measured at 3 hourly basis $(3,6,9,12,15,18,21,24 \mathrm{~h})$. The gas produced was read by measuring the space formed between the top of the piston and the liquid in the syringe. At the termination of the $24 \mathrm{~h}$ of incubation, $4 \mathrm{ml}$ of $\mathrm{NaOH}(10 \mathrm{M})$ was introduced to each of the syringes containing the samples for methane $\left(\mathrm{CH}_{4}\right)$ gas determination. The gas volume was determined by difference, by subtracting the average gas production values of the blank from the individual feed samples. $\mathrm{CO}_{2}$ was determined by subtracting the $\mathrm{CH}_{4}$ gas production from the gas volume.

\section{Metabolizable energy, organic matter digestibility and Short chain fatty acid estimation}

Metabolizable energy was estimated as ( $\mathrm{ME}, \mathrm{MJ} / \mathrm{kgDM}$ ) $=2.20+0.136^{\star} \mathrm{Gv}+0.057^{\star} \mathrm{CP}+0.0029^{*} \mathrm{CF}$ (Menke and Steingass, 1988). Similarly, organic matter digestibility was estimated as $(\mathrm{OMD} \%)=14.88+0.889^{*} \mathrm{Gv}+$ $0.45 \mathrm{CP}+0.0651^{*} \mathrm{XA}$ (Menke and Steingass 1988). While short chain fatty acid was estimated as (SCFA) = $0.0239^{*} \mathrm{Gv}-0.0601$ (Getachew, et al., 1999); where Gv, $\mathrm{CP}, \mathrm{CF}$ and $\mathrm{XA}$ are net gas production ( $\mathrm{ml} / 200 \mathrm{mg} \mathrm{DM})$, crude protein, crude fibre and ash of the incubated samples respectively.

\section{Statistical analysis}

Data obtained from the in vitro studies and chemical analysis was analyzed using analysis of variance (ANOVA) as described by (SAS, 1999). Means were separated using the Duncan Multiple Range Test (Steel and Torrie, 1980).

\section{RESULTS AND DISCUSSION}

The proximate nutrient composition of experimental diets supplemented with crop by-products (peels) and maize used for the in vitro gas production technique is presented in Table 2 . There were significant $(P<0.05)$ variations in dry matter (DM), ash, crude protein (CP), Nitrogen free extract (NFE), crude fibre (CF), ether extract (EE) and acid detergent (ADF). However, the neutral detergent fibre (NDF) content in the feed mixtures of maize (TM) and cheap energy based crop by-products of cassava peels (TCP), yam peels (TYP) and plantain peels (TPP) in the experimental diets were not significantly $(P>0.05)$ different. The ash contents of the experimental diets were in the increasing order of 9.35, 9.97, 10.53 and $13.13 \%$ for TYP, TM, TPP and TCP respectively. The highest ash content was recorded by the feed mixture containing cassava peel (TCP). The crude protein (CP) content of the feed mixtures were within the range of $6.07-11.21 \%$ with TYP recording the lowest CP content and TPP recording the highest CP content, although the values recorded by TPP were not statistically different from those of TM. A trend in the increase of the CP contents of the diets were observed because of the additive or contributory effects of the $\mathrm{CP}$ contents of the supplemental conventional (TM) and non-conventional (TCP, TPP and TYP) energy based feed stuffs used for formulating the experimental diets. Thus the increase in the CP contents of TPP supplemented diet for instance, may be attributed to the higher CP contents of TPP (7.37\%) (Kalio, et al., 2014).

The experimental diets comprised of a mixture of concentrates (conventional and non-conventional feed stuffs) in a roughage (fibre) base of Panicum maximum perennial grass in a ratio of $40 \%: 60 \%$ respectively. This is necessary because, ruminant animals require a minimum amount of fibre to maintain good rumen function by stimulating cud chewing, rumen movement and the production of saliva for buffering acidic conditions in the rumen so as to to maintain the microbial population in the rumen (Stokes and Prostko, 2016). The Neutral detergent fibre (NDF) measures all the fiber found in the diet (hemicellulose, cellulose and lignin). The Acid detergent fiber measures the cellulose and lignin content of plant origin in the diets (Stokes and Prostko, 2016). Thus the Acid detergent fibre (ADF) contents of the experimental diets were significantly $(P<$ $0.05)$ different with the highest value recorded for the cassava peel (TCP - 31.50\%) supplemented diets as opposed to the plantain peel (TPP $-29.50 \%$ ), yam peel (TYP - 28.00\%) and whole maize (TM - 23.00\%) experimental groups respectively. Similarly, the trend in the increase of the ADF contents of the diets were observed because of the additive or contributory effects of the ADF contents of the supplemental non- 
conventional (TCP, TPP and TYP) and conventional (TM) energy based feed stuffs used for formulating the experimental diets. Thus the increase in the ADF contents of TCP supplemented diet for instance, may be attributed to the higher ADF contents of TCP $(31.50 \%)$ (Kalio, et al., 2014). Conversely, the Neutral detergent fibre (NDF) contents of the experimental diets were not significantly $(P>0.05)$ different.

The estimated Metabolisable energy (ME), short chain fatty acid (SCFA) and organic matter digestibility (OMD) of diets supplemented with maize and crop byproducts used as energy sources in the experiment is presented in Table 3.There were significant variations $(P$ $<0.05$ ) in the metabolizable energy (ME) and organic matter digestibility (OMD) among the experimental diets. However, the short chain fatty acids (SCFAs) produced with the different experimental diets were not significantly $(P>0.05)$ different.

The metabolizable energy (ME) of the different experimental diets in order of decreasing values after 24 hours of incubation were 7.20, 6.09, 5.98 and 5.97 $\mathrm{MJ} / \mathrm{kgDM}$ for TCP, TPP, TM) and TYP respectively. However, the metabolizable energy of the feedstuffs: TPP, TM and TYP were not significantly $(P>0.05)$ different. The results revealed that the cassava peel (TCP) supplemented energy based diets possess a higher ME value than the ME values for TPP, TM and TYP. The ME values recorded in this study by TCP and TPP revealed that the metabolizable energy of these two diets were within the recommended ME values for an average diet $(6-13 \mathrm{MJ} / \mathrm{kg} / \mathrm{DM})$ (Steele, 2006), hence can fulfill the energy requirements for WAD sheep and goats when utilized.

The short chain fatty acids (SCFAs) or volatile fatty acids of the different diets in order of decreasing values after 24 hours of incubation were $0.53,0.50,0.48$ and $0.45 \mu \mathrm{M}$ for TYP, TPP, TM and TCP respectively. The SCFA value of the diet containing TYP was higher, although they were not significantly $(P>0.05)$ different from those of the TPP, TM and TCP treatment groups respectively. The TYP and TPP treatment groups recorded the highest value of SCFAs. The SCFAs or volatile fatty acids such as acetic, propionic, butyric, isobutyric, valeric, isovaleric, 2-methylbutyric, hexanoic and heptanoic acids have been reported as a major source of energy as well as a building block for milk synthesis (Bergman, 1990). Thus the TYP and TPP diets having recorded the highest value of SCFAs have better potentials to fulfill this role. Similarly, the results of the SCFAs for these diets have also been corroborated by the range $(6-13 \mathrm{MJ} / \mathrm{kg} / \mathrm{DM})$ of $\mathrm{ME}$ values for these diets. This will therefore give a strong assurance for the provision of up to $80 \%$ of maintenance energy for WAD goats and sheep or any other ruminant when fed with this diet (Bergman, 1990)

The organic matter digestibility (OMD) of the different diets in order of decreasing values after 24 hours of incubation were 48.71, 41.36, 40.62 and $40.15 \%$ for TCP, TPP, TM and TYP respectively. The $\mathrm{OMD}$ values recorded in this study were within the range $(7.76$ - 65.98\%) of the OMD values recorded by Chumpawadee, et al. (2007) in their studies while investigating the chemical compositions and nutritional evaluation of energy feeds for ruminant using in vitro gas production technique after 24 hours incubation of the feed samples. This study revealed that the feed mixtures supplemented with cassava peels (TCP) recorded the highest OMD after 24 hours of incubation.

Table 2: Proximate nutrient composition of experimental diets supplemented with crop byproducts (peels) and maize used for the in vitro gas production technique

\begin{tabular}{|c|c|c|c|c|c|c|}
\hline \multirow{2}{*}{$\begin{array}{c}\text { Constituents } \\
(\%)\end{array}$} & \multicolumn{6}{|c|}{ Diet composition with Crop by-products (peels) } \\
\hline & TM & TCP & TPP & TYP & Mean & \pm SEM \\
\hline DM & $93.65^{\mathrm{a}}$ & $83.84^{\mathrm{d}}$ & $88.29^{5}$ & $85.64^{c}$ & 87.86 & 0.35 \\
\hline Ash & $9.97^{\mathrm{C}}$ & $13.13^{\mathrm{a}}$ & $10.53^{\mathrm{b}}$ & $9.35^{d}$ & 10.75 & 0.23 \\
\hline $\mathrm{CP}$ & $10.97^{\mathrm{ab}}$ & $10.07^{\mathrm{b}}$ & $11.21^{\mathrm{a}}$ & $6.07^{\mathrm{c}}$ & 9.58 & 0.97 \\
\hline NFE & $51.08^{\mathrm{b}}$ & $48.97^{d}$ & $49.53^{c}$ & $57.97^{\mathrm{a}}$ & 51.89 & 0.20 \\
\hline $\mathrm{CF}$ & $24.32^{\mathrm{b}}$ & $25.14^{\mathrm{a}}$ & $25.53^{\mathrm{a}}$ & $23.53^{\mathrm{c}}$ & 24.63 & 0.31 \\
\hline EE & $3.42^{\mathrm{a}}$ & $2.42^{\mathrm{b}}$ & $3.52^{\mathrm{a}}$ & $3.33^{a}$ & 3.17 & 0.26 \\
\hline ADF & $23.00^{d}$ & $31.50^{\mathrm{a}}$ & $29.50^{\mathrm{b}}$ & $28.00^{C}$ & 28.00 & 0.77 \\
\hline NDF & $52.00^{\mathrm{ns}}$ & $53.50^{\mathrm{ns}}$ & $53.00^{\mathrm{ns}}$ & $53.00^{\mathrm{ns}}$ & 52.88 & 0.61 \\
\hline
\end{tabular}

a,b,c,d Means bearing different superscripts along the same row are significantly different $(P<0.05), \mathrm{NS}=$ Non-significant, $\mathrm{TM}=$ Maize, $\mathrm{TCP}=$ Cassava peels, TPP $=$ Plantain peels, TYP $=$ Yam peels, $\mathrm{DM}=\mathrm{Dry}$ matter, $\mathrm{CP}=$ Crude protein, NFE $=$ Nitrogen free extract, $\mathrm{CF}=$ Crude fibre, $\mathrm{EE}=$ Ether extract, $\mathrm{ADF}=$ Acid detergent fibre. 
Table 3: Estimated Metabolizable energy (ME), short chain fatty acid (SCFA) and organic matter digestibility (OMD) of diets supplemented maize and crop by-products used as energy sources Parameters
TM

Experimental Diets with maize and crop by-products (peels)

TM

\begin{tabular}{|c|c|c|c|c|c|c|}
\hline $\begin{array}{l}\text { Gas volume (Gv) } \\
(\mathrm{ml} / 200 \mathrm{mgDM})\end{array}$ & $22.70^{\mathrm{b}}$ & $32.00^{a}$ & $23.30^{\mathrm{b}}$ & $24.70^{\mathrm{b}}$ & 25.68 & 6.45 \\
\hline $\begin{array}{l}\text { Metabolizable energy } \\
\text { (ME) (MJ/kgDM) }\end{array}$ & $5.98^{b}$ & $7.20^{\mathrm{a}}$ & $6.09^{b}$ & $5.97^{b}$ & 6.31 & 0.36 \\
\hline $\begin{array}{l}\text { Short chain fatty acids } \\
\text { (SCFA) ( } u \text { M) }\end{array}$ & $0.48^{\mathrm{ns}}$ & $0.45^{\mathrm{ns}}$ & $0.50^{\mathrm{ns}}$ & $0.53^{\mathrm{ns}}$ & 0.49 & 0.16 \\
\hline $\begin{array}{l}\text { Organic matter } \\
\text { digestibility }(\mathrm{OMD})(\%)\end{array}$ & $40.62^{\mathrm{b}}$ & $48.71^{a}$ & $41.36^{\mathrm{b}}$ & $40.15^{\mathrm{b}}$ & 42.71 & 2.30 \\
\hline
\end{tabular}

$\overline{a, b, c,}$ Meansbearing different superscripts along the same row are significantly different

$(P<0.05) ; \mathrm{TM}=$ Maize, TCP $=$ Cassava peels, TPP $=$ Plantain peels, TYP $=$ Yam peels, Metabolizable energy (ME) $(\mathrm{MJ} / \mathrm{kgDM})=2.20+0.136^{*} \mathrm{Gv}+0.057^{\star} \mathrm{CP}+0.0029^{*} \mathrm{CF}$; Organic matter digestibility $(\mathrm{OMD})(\%)=14.88+0.889^{*} \mathrm{Gv}+0.45^{\star} \mathrm{CP}+0.0651^{*} \mathrm{XA}$; Short chain fatty acids (SCFA) $(\mu \mathrm{M})=0.0239^{*} \mathrm{Gv}$ $-0.0601 ; \mathrm{Gv}=$ Gas volume $; \mathrm{CP}=$ Crude protein; $\mathrm{CF}=$ Crude fibre $; \mathrm{XA}=$ Ash.

\section{CONCLUSION}

The results of this study revealed that the cassava peel (TCP) supplemented energy based diets possess a higher ME value than the ME values for the plantain peel (TPP), maize (TM) and yam peel (TYP) supplemented diets. The ME values recorded in this study by TCP and TPP revealed that the metabolizable energy of these two diets were within the recommended ME values for an average diet $(6-13 \mathrm{MJ} / \mathrm{kg} / \mathrm{DM})$; hence can fulfill the energy requirements for small ruminants when utilized. Similarly, the TYP and TPP treatment groups recorded the highest value of SCFAs. The SCFAs or volatile fatty are a major source of energy as well as a building block for milk synthesis. Thus the TYP and TPP diets having recorded the highest value of SCFAs will have better potentials to fulfill this role in sheep and goats. Furthermore, this study also revealed that the feed mixtures supplemented with cassava peels (TCP) recorded the highest organic matter digestibility (OMD) after 24 hours of incubation. It is therefore recommended that non-conventional feedstuffs such as crop byproducts could be better substitutes as energy sources in sheep and goat diets on account of their nutritional value in terms of metabolizable energy (ME), short chain fatty acids (SCFAs) and organic matter digestibility (OMD) as well as their ready availability and predominance, cheapness and better economic gains to small ruminant farmers.

\section{REFERENCES}

Adegbola, T.A, Ogbonna, R.C and Nwachukwu, N.E (1988). Nutrient Intake, Digestibility and Rumen Studies in Goats fed varying levels of cassava peels and brewer's dried grain. Nigeran.Journal of Animal Production.15: 161 - 166.
Babayemi, O.J., Otukoye, F.K., Femilade, F.O. \& Daodu, M.O. (2009). Assessment of the nutritive value of bovine liquor and urea treated corn-straw and corncobs as feed for the West African Dwarf sheep and goats. Nigerian Journal of Animal.Production. 36(2): 313- 324.

Bergman, E.N. (1990). Energy contributions of volatile fatty acids from the gastrointestinal tract in various species. Physiology Review. 70: 567-590.

Chumpawadee, S., Chantiratikul, A. and Chantiratikul, P. (2007). Chemical Compositions and Nutritional Evaluation of Energy Feeds For Ruminant Using In vitro Gas Production Technique. Pakistan Journal of Nutrition 6 (6): 607-612.

Devendra, C. (1989). Non-conventional feeds: Potential value for animals in the Asian Region. Outlook on Agriculture, 18 (2): $58-64$.

Getachew, G., Makkar, H.P.S and Becker, K. (1999). Stoichiometric relationship between short chain fatty acid and in vitro gas production in presence and absence of polyethylene glycol for tannin containing browses, EAAP Satellite Symposium, Gas production: fermentation kinetics for feed evaluation and to assess microbial activity, 18 - 19 August, 1999, Wageningen, The Netherlands.

Kalio, G.A., Ayuk, A.A. and Agwunobi, L.N. (2014). Performance of West African Dwarf (WAD) Goats Fed N-treated Source and Forage Supplemented Cassava Peels in Humid Cross River State, Nigeria. American Journal of Experimental Agriculture, 4(6): 629-638.

Menke, K.H. and Steingass, H. (1988). Estimation of the energetic feed value from chemical analysis and in vitro gas production using rumen fluid. Animal Research and Development. 28: 27 - 35.

Statistical Analytical Systems (SAS) (1999).SAS for Users Guide Statistics.SAS Inc: Cary, North Caroline. 
Steel, R.G.D. and Torrie, J.H. (1980).Principles and procedures of Statistics. Biometric Approach $\left(2^{\text {nd }}\right.$ Edition) McGraw Hill Co.Inc., New York, USA.

Steele, M. (2006). Goats. CTA-Macmillan Publishing Ltd., London and Basingstoke.(152 pp).
Stokes, S.R. and Prostko, E.P. (2016). Understanding Forage Quality Analysis. Extension Dairy Specialist and Extension Agronomist, The Texas A\&M University System.

Cite this Article: Kalio GA (2017). Metabolizable Energy and Digestibility Estimates of mixed Diets of Crop By-Products as Readily Available Feeds for Small Ruminants. Greener Journal of Agricultural Sciences, 7(8): 210-215, http://doi.org/10.15580/GJAS.2017.8.101417150. 